\title{
Buildings with suspended structures in seismic areas
}

\section{Здания с подвесными конструкциями в сейсмических районах}

\author{
T.A. Belash, \\ P.L. Rybakov, \\ Petersburg State Transport University, \\ St. Petersburg, Russia
}

Key words: seismic; suspended structures; oscillations period; finite element method

\author{
д-р техн. наук, профессор Т.А. Белаш, \\ магистр П.Л. Рыбаков, \\ Петербургский государственный \\ университет путей сообщения \\ Императора Александра I, Санкт- \\ Петербург, Россия
}

\author{
Ключевые слова: сейсмостойкость; \\ подвесные конструкции; период колебания; \\ метод конечных элементов
}

\begin{abstract}
Using suspended structures in construction is one of the methods to improve the earthquake buildings resistance. This subject became very popular in the 60-70s of the 20th century. However, at that time there were no available methods to provide full studies devoted to the buildings of this type. Soon, however, the opportunity appeared due to the development of computer engineering. This caused further analysis and disclosure of the full potential of suspension systems. This article discusses five different structural layouts including using suspended structures. SOFiSTiK computer system was used to calculate them. The time of oscillations was the main criterion to evaluate the schemes. It is well-known that earthquake exposure on the building decreases if the time of oscillations increases. It was found that the time of oscillations of the buildings with suspended structures is greater by several times in comparison with the buildings with traditional structural system. Taken into consideration the given fact, we can suggest that the efficiency of suspension systems in seismic conditions is provided.
\end{abstract}

Аннотация. Использование подвесных конструкций в строительстве, является одним из способов повышения сейсмостойкости зданий. Данная тема получила наибольшую популярность в 60-70x годах 20 века. Однако в то время не существовало доступных методов для полноценного исследования зданий такого типа. В результате развития вычислительной техники, такая возможность появилась. Это послужило причиной дальнейшего анализа и раскрытия всего потенциала подвесных систем. В статье рассмотрено пять различных конструктивных схем зданий, в том числе с использованием подвесных конструкций. Для их расчёта использовался программно вычислительный комплекс SOFISTiK. Основным критерием оценки схем стал период собственных форм колебания. Как известно, при увеличении периода, уменьшается сейсмическая нагрузка, действующая на здание. Было выявлено, что период колебания у зданий с подвесными конструкциями в несколько раз больше, чем у зданий с традиционной конструктивной системой. Этот фракт позволяет говорить о том, что эффективность подвесных систем в условиях сейсмики обеспечивается.

\section{Introduction}

Increased seismic stability of buildings can be achieved in various ways. There are many approaches designed to handle this challenging task in Russian and global practice. One of them is the search for the most efficient and reliable structural systems among which buildings with suspended structures form a separate group. Suspended systems of buildings are characterized by a variety of geometric shapes that depends on installation methods, cost, the duration of erection, and space and layout requirements. The s]solutions put forward by Russian experts to increase seismic stability through the use of suspended structures have been previously reflected in the works by I.L. Korchinsky, N.N. Skladnev, G.Sh. Chanukvadze, P.I. Ostromensky, I.I. Grigorieva [1-6].

Most of the research in this area was conducted in the 60-70s of the 20th century. During the same period some suspended-type buildings were erected both in earthquake-prone and in safe areas of the globe - in Antwerp, Mexico City, Vancouver, London, Munich, Madrid, Minneapolis (USA), Kota Kinabalu (Malaysia) [7-14]. In 1979, American expert Wolfgang Schuller was the first who codified the

Белаш Т.А., Рыбаков П.Л. Здания с подвесными конструкциями в сейсмических районах // Инженерностроительный журнал. 2016. № 5(65). С. 17-26. 
classification of suspended systems [15]. The rigid shaft principle is applied in the design of most suspended buildings.

Although experts from Russia and the former USSR were also conducting some research and searching for solutions of buildings with suspended structures, none of them was built. One of such solutions was a suspended building proposed and patented by I.L. Korchinsky in 1971. In this model, loads are transferred from floors to the foundation entirely through trusses located at the top of the shaft. Seismic stability increased due to the fact that the structure design was fitted out with extra dampers placed at the points where suspensions were attached to trusses and at the points where trusses were supported by the shaft (Fig. 1) [1].

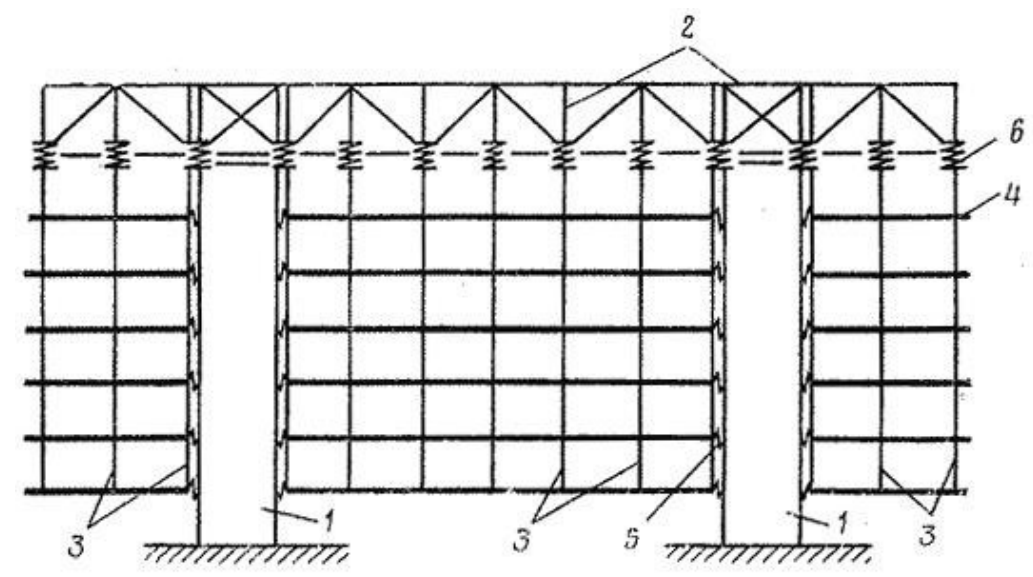

Figure 1. Suspended building: 1 - reinforced concrete shaft;

2 - double-cantilever trusses; 3 - suspensions; 4 - suspended floors;

5 - dampers in the form of elastic links; 6 - extra dampers

In 1976, G.Sh. Chanukvadze developed another model of an earthquake-proof building with suspended structures. The complicated damper system was considered to be the main drawback of the building option proposed by I.L. Korchinsky.

In the proposed solution, suspensions were made prestressed and junctions of floors and the central core - rigid and swivel with floor-by-floor alternation (Fig. 2). Thus, loads were transferred to the foundation partly through the shaft truss and partly through cantilevered supports on the shaft itself. According to the author, this design was to reduce arising forces affecting the building and caused by wind and seismic effects [3].

Afterwards, the model was further refined by its authors in order to avoid possible resonance in the event of heavy earthquakes. For this purpose, suspensions anchored in the foundation were equipped with shutoff links (Fig. 3) [4].

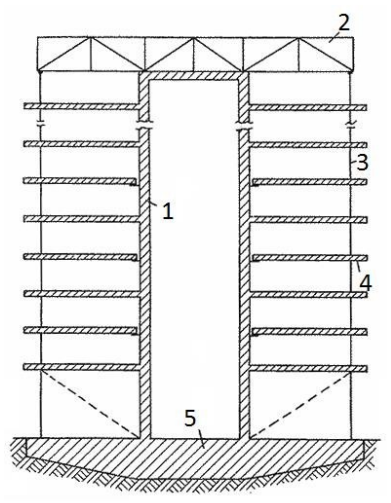

Figure 2. Suspended building: 1 - core; 2 - truss; 3 - suspensions; 4 - floors; 5 - foundation

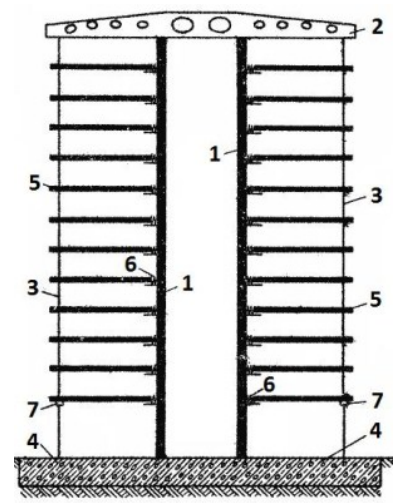

Figure 3. Suspended building: 1 - core; 2 - truss; 3 - suspensions; 4 - foundation; 5 - floors; 6 - pivots; 7 - shutoff links

N.N. Skladnev, an expert of the Central Research Institute of Construction Structures named after Kucherenko [2], made a great contribution to the study of the operation of suspended systems in seismic conditions.

Belash T.A., Rybakov P.L. Buildings with suspended structures in seismic areas. Magazine of Civil Engineering. 2016. No. 5. Pp. 17-26. doi: 10.5862/MCE.65.2 
Currently, the development and construction of buildings with suspended structures are almost abandoned. The reason for this may be the fact that the solutions proposed previously have proved to be difficult to implement on the engineering side. In addition, calculation methods that existed before the 90s could not fully reflect the nature of effects of the seismic impact. Consequently, the study of these systems was suspended.

However, along with increasingly sophisticated computer technologies and increased capacities of electronic computers, methods to calculate mathematical models are being elaborated as well. Computing complexes are continuously emerging and they are being updated. They are capable to perform the most complicated tasks in the field of dynamic linear and nonlinear oscillations.

SOFiSTiK is one of such complexes. There is a wide range of design and load simulation capabilities among the features of SOFiSTiK. Another advantage of this complex is a possibility to work with macros that allow you to make adjustments to any computation module by using programming language CADINP [16].

State-of-the-art capabilities of this computation complex enable us to proceed with research into the system of buildings with suspended structures that is somewhat abandoned, but not very explored.

Research objective was carrying out the comparative analysis of dynamic parameters (the period and the frequency of natural oscillations) buildings with suspended constructions.

\section{Methods}

One of the most common building configurations in the form of a cantilevered cap on a single shaft in the shape of a cylinder as per the classification by Wolfgang Schuller was taken to pursue the research [15]. The chosen shape corresponds to several basic theses of the efficient configuration of buildings in seismic areas [17]. Then, five options of computational schemes were selected. Eeach of them was distinguished by different structural solutions affecting dynamic characteristics of a building. The work took into consideration the experience of Russian experts in the field of automated computation [18, 19]. The standard module "Natural modes and frequencies" of SCC SOFiSTiK was used to determine the frequency.

As is well-known, in current standards the value of seismic load for the $i$-th mode of natural oscillations of buildings or facilities $-S_{0 i k}^{j}$ - is conventionally calculated by the following formula:

$$
S_{0 i k}^{j}=g m_{k}^{j} A K_{A} \beta_{i} K_{\psi} \eta_{i k}^{J}
$$

where $m_{k}^{j}$ - the mass of the building or the moment of inertia of the corresponding mass of the building; $g$ - acceleration due to gravity; A - the factor which values should be taken on the basis of the estimated seismicity; $\mathrm{K}_{\mathrm{A}}$ - the factor which value should be taken depending on combinations of the estimated seismic intensity; $\beta_{i}$ - the dynamic factor corresponding to the $i$-th mode of natural oscillations of buildings or facilities; $K_{\psi}$ - the damping factor; $\eta_{i k}^{J}$ - the factor depending on the mode of building or facility deformation under its natural oscillations by the $i$-th mode.

The value of the dynamic factor $\beta_{i}$ should be taken as per the graph (Fig. 4) depending on the estimated period of natural oscillations $T_{i}$ of a building or facility by the $i$-th mode.

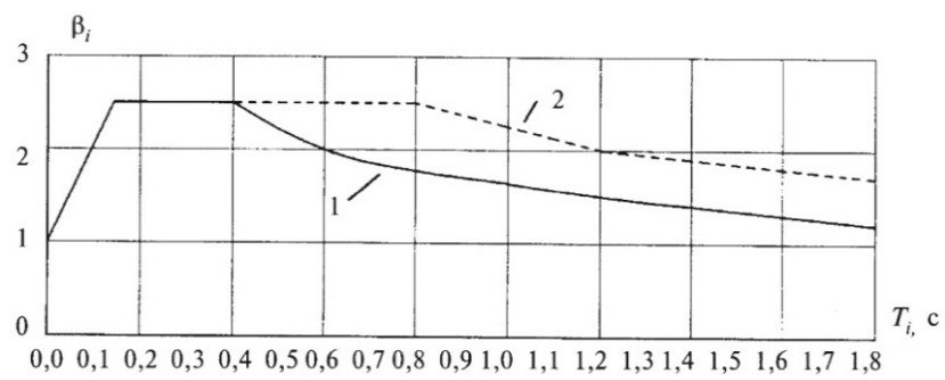

Figure 4. Dependence of the dynamic factor on the period of natural oscillations: 1 - curve for soils of Category I and II; 2 - curve for soils of Category III

The graph shown above clearly illustrates that the dynamic factor decreases along with an increase in the natural oscillation period that ultimately reduces the seismic load. This fact is a stimulus for low-frequency adjustment of a building, which can be implemented in particular due to the introduction 
of suspended structures. Therefore, at the first stage of the research, the period of natural oscillations was the key parameter that determined efficiency of the considered schemes.

\section{Results and Discussion}

The first scheme of the building has a conventional shaft system without the use of special means to ensure seismic protection. In this scheme, the load is transferred from floors to the foundation through the rigid reinforced concrete shaft and metal $\mathrm{H}$-columns placed along the perimeter. In the first scheme as in the rest, the foundation is taken as a solid slab. Figure 5 shows the computational scheme of the building and its model from the software complex SOFiSTiK.

The standard module "own forms and frequencies" was used to determine the frequency of own forms of oscillations. The calculation was made by the ASE module with a choice of the following parameters: the number of forms of oscillations -6 , the computation was carried by Lantsosh's method, the attenuation factor according to Rayleigh was accepted by- $5 \%$. Columns, plates, beams - slabby, rod and beam terminal elements were used for the bearing structural elements.

The model of the building has 13 floors, the height of the floor is accepted by $4 \mathrm{~m}$, the diameter of a trunk is equal to $8 \mathrm{~m}$, the external diameter is equal to $20 \mathrm{~m}$. The walls of a kernel and overlapping are made of monolithic reinforced concrete $0.3 \mathrm{~m}$ thick. Sixteen metal columns which are replaced further with guys are located on perimeter of the building. The base is executed in the form of a monolithic reinforced concrete plate $2 \mathrm{~m}$ thick, with a diameter of $20 \mathrm{~m}$. The console grillage at building top holding guys is executed in the form of a reinforced concrete plate $0.6 \mathrm{~m}$ thick. He is supported by inclined metal beams on trunk tops.

For reinforced concrete designs B 25 concrete and A 400 fittings is accepted. Columns are made of steel C 245 with a profile 20K2. This model was used for comparison with other settlement schemes.

The computation of this scheme made it possible to determine its oscillation period equal to 1.08 seconds.

The second scheme is similar to the first one, but it still differs from it since it has a seismic isolation system represented by rubber-metal supports (RMS) installed in the foundation. The principle of this system operation consists in increasing the period of natural oscillations of structures thereby the seismic load on the building decreases.

To consider the operation of the seismic isolation system, another foundation slab was included into the model at the distance of $1 \mathrm{~m}$ from the first. Point links were arranged between the slabs simulating RMS operation, which enable us to secure the element not pivotally but movably along its axes with the required rigidity. Lateral rigidity of rubber-metal supports is much less than longitudinal thereby they allow the structures mounted on them to oscillate horizontally while remaining at the design elevation. This RMS property was taken into account when setting the parameters of Point links. The oscillation period of a building of this scheme amounted to 2.49 seconds.

a)

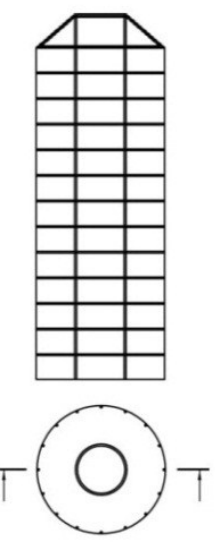

b)

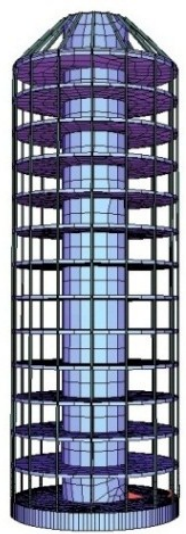

Figure 5. First computational scheme:

a) structural layout; b) computational model of SOFiSTiK program

Figure 6 shows the features of the scheme and computational model.

The third scheme was drawn up considering the operation of the system of suspended structures. When modeling all schemes of this type, the specificity of cable-stayed structures described in various Belash T.A., Rybakov P.L. Buildings with suspended structures in seismic areas. Magazine of Civil Engineering. 2016. No. 5. Pp. 17-26. doi: 10.5862/MCE.65.2 
works was taken into consideration [20-32]. For the comparative analysis of all five schemes to be objective, the building configuration was retained and the columns were replaced with cable stays. In this scheme, the load was transferred from floors to the foundation according to the type of suspended building by Chanukvadze G.Sh. [3] - partly through cable stays and grillage at the shaft top, partly through cantilevered supports on the shaft itself. Grillage means a space structure holding cable stays and consisting of a reinforced concrete slab, sloping metal beams and continuation of the shaft walls.

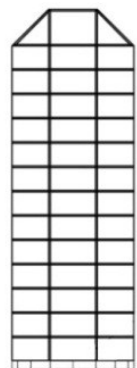

a)

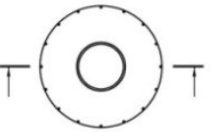

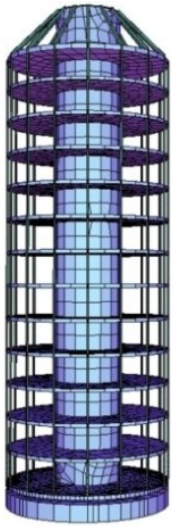

b)

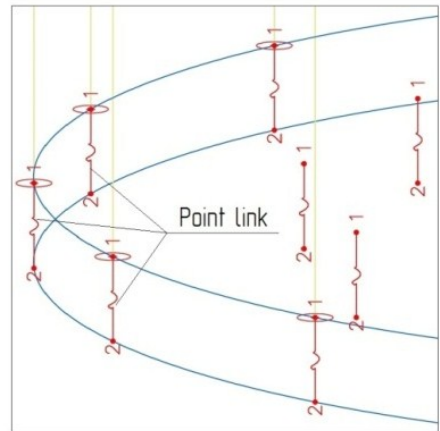

c)

Figure 6. Second computational scheme:

a) structural layout; b) computational model of SOFiSTiK program; c) display of Point links in SOFiPLUS preprocessor

The units where floors were supported by the shaft were made by means of an elastic link element - Point link. The operating principle of these elements remained the same as in the previous scheme. Each floor disc was supported at 16 link points having lateral rigidity much less than longitudinal which enabled the floor discs to oscillate relatively freely in the horizontal direction. Figure 7 shows the scheme of the floor support unit and its representation in SOFiPLUS. Figure 8 shows the computational scheme and model of the third option.

The scheme parameters are dependent on the lateral rigidity of supports, which can vary depending on the desired period of the model oscillation. As it has been said above, the seismic load decreases along with the decrease in the dynamic factor, consequently, the maximum period of oscillation is the most efficient [33-36].

To determine the dependencies and search for an option with the greatest period, the lateral rigidity of each support varied from $25 \mathrm{kN}$ to $175 \mathrm{kN}$ in increments of $25 \mathrm{kN}$. The variation range was taken considering the actual rigidity of support elements. The period ranged from 4.83 to 2.13 seconds. Since a floor disc was supported by 16 supports, the total increment of rigidity variation per floor was $400 \mathrm{kN}(25 \mathrm{kN} \times 16=400 \mathrm{kN})$.

a)

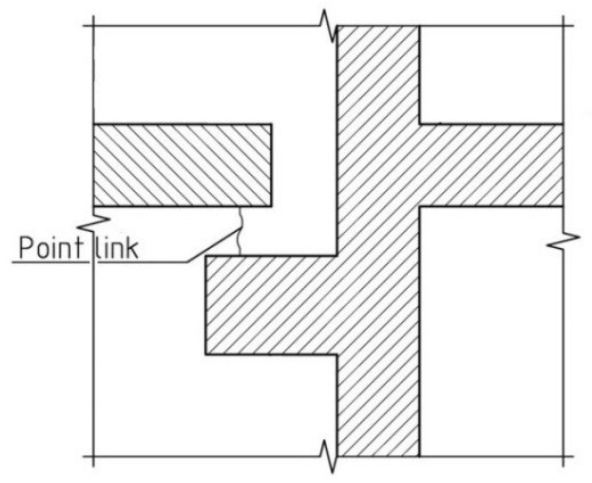

b)

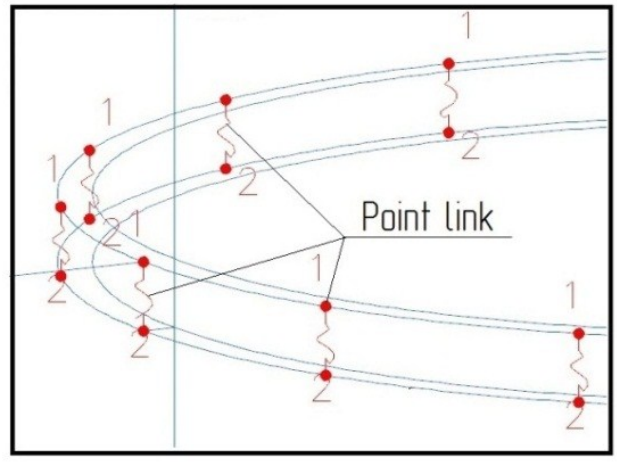

Figure 7. Floor support unit:

Белаш Т.А., Рыбаков П.Л. Здания с подвесными конструкциями в сейсмических районах // Инженерностроительный журнал. 2016. № 5(65). С. 17-26. 

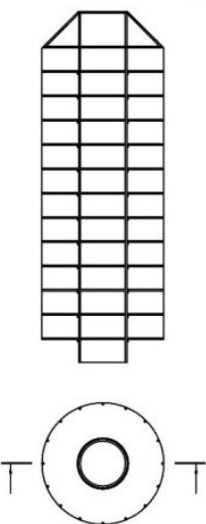

a)

Figure 8. Third computational scheme of the building:

a) structural layout; b) computational model of SOFiSTiK program

The fourth computational scheme uses the suspended system as well. The difference between this scheme and the previous scheme consists in the fact that floor discs are suspended by cable stays not just along the outer contour, but also along the inner contour. In this scheme, the loads are transferred from floors to the foundation solely through the shaft grillage as per the example of the building according to Korchinsky I.L. [1]. Figure 9 shows the features of the structural layout and computational model.

a)
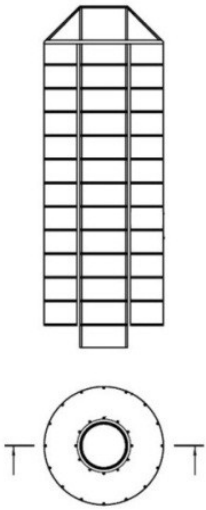

b)



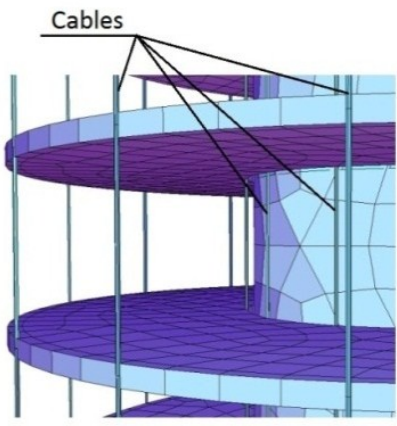

c)

Figure 9. Fourth computational scheme of the building: a) structural layout;

b) computational model of SOFiSTiK program;

c) enlarged area of the model showing the location of cable stays in it

To analyze this scheme, the parameters affecting the oscillation period that varied during the study were determined. Firstly, the building height ranged from 4 to 18 storeys in increments of 2 storeys. In all schemes, the storey height was equal to $4 \mathrm{~m}$. As a result, it was found that within the considered range of variation in the building height, the period of natural oscillations ranged from 7 to 14.7 seconds.

The second parameter of variation was the weight of the lower suspended floor, which varied from $300 \mathrm{t}$ to $1400 \mathrm{t}$ in increments of about $150 \mathrm{t}$. The change in this parameter allowed extending the oscillation period of a 5-storey model from 7.1 to 7.63 seconds, but it did not virtually affect the properties of a 15-storey model.

The evaluation of dynamic parameters of the fourth scheme shows that it is possible to substantially extend the period of natural oscillations and achieve the maximum reduction of seismic load on the building in a structural way. However, due to considerable yield such systems lead to swinging of suspended elements that can cause the destruction of the entire building.

If we follow the recommendations to design buildings on seismic isolating structures of foundations $[37,38]$, and for multi-storey buildings as well, the duration of the most efficient period of natural oscillations ranges from 3 to 4 seconds. Apparently, the oscillation period falling within this range is also the most preferable for buildings with suspended structures. 
At the next stage, we considered the fifth computational scheme of a building with suspended structures. It took into account advantages and drawbacks of the previous schemes. The main drawback of the third scheme is high cost and complexity of cantilevered supports, as well as their difficult maintenance. The drawback of the fourth scheme is the uncontrolled oscillation of suspended elements, which may cause resonance in case of seismic exposure.

The fifth computational scheme combines the positive aspects of the third option - the possibility to adjust the rigidity of supports and oscillation amplitude. The fourth option - the relative simplicity of design and maintenance alongside with reliability.

The fifth scheme is similar to the third one, but in this case, floor discs are attached to the shaft by means of cable suspensions. Figure 10 shows the features of the structural layout and model.

a)
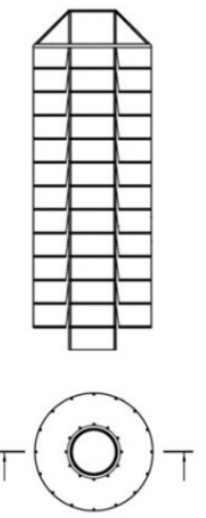

b)

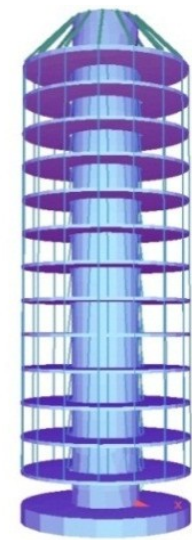

Figure 10. Fifth computational scheme of the building: a) structural layout; b) computational model of SOFiSTiK program;

c) enlarged area of the model showing the location of cable stays in it

The principle of the operation of cable suspensions is based on the properties of a mathematical pendulum. When floors oscillate because of seismic exposure, the angle of the deviation of suspensions is increasing and, consequently, the force tending to place the floor back is also increasing.

While studying this computational scheme, the length of suspensions, the angle of their deviation from the vertical and the height of the building varied. The length ranged from $0.9 \mathrm{~m}$ to $4.4 \mathrm{~m}$ in increments of $0.5 \mathrm{~m}$. The deviation angle changed from $0^{\circ}$ to $6^{\circ}$ with an interval of $1.5^{\circ}$. The height of the building varied from 4 to 18 storeys in increments of 2 storeys.

After all the computations, it was found that the maximum period of oscillation -4.71 seconds belongs to a building having the maximum length and minimum angle of deviation of suspensions, as well as the maximum height.

It is worth noting that at the minimum angle of the deviation of cable stays there is the need to install cantilevers thereby the storey area may be reduced. To avoid this, the maximum displacement of suspended elements should be less than the distance between the suspended and non-suspended part of the building.

\section{Conclusions}

Based on the results of the research conducted the following conclusions were drawn:

1. Buildings with suspended structures can be considered as earthquake-proof systems and their use may result in a significant reduction of seismic loads.

2. Decrease in seismic loading in buildings with suspended designs is connected with the reduction of the coefficient of dynamism due to increase in the period of own fluctuations.

3. The results of the comparative analysis of various versions of settlement schemes established that the fifth settlement scheme with use of guy suspensions, the second scheme with the use of rubbermetal support and the third scheme are the most effective for multi-storey buildings with suspended designs. 
4. The fourth scheme has the greatest period of own fluctuations, but in case of this scheme the building can receive a serious swing during an earthquake that as a result will lead to its collapse.This scheme is unserviceable without the introduction of oscillation damping elements.

5. The first scheme with traditional barreled constructive system has the form of fluctuations similar to the fluctuations of the console compressed core. The maximum period of own fluctuations in this scheme did not exceed $1.08 \mathrm{sec}$.

6. The findings form the basis for further research considering actual characteristics of seismic effects [39].

\section{References}

1. Korchinsky I.L., Grill A.A., Chernyavsky I.Z., Popov I.V., Kaplan V.E., Fridburg V.I. Podvesnoe zdanie [Suspended building]. SU USSR 477227. 1975 (rus)

2. Skladnev N. N. Vysotnye zdaniya s zhyostkim stvolom $i$ podveshennymi na predvaritel'no napryazhyonnyh vantah ehtazhami, prednaznachennye dlya sejsmicheskih rajonov [The high-rise buildings with a rigid trunk and floors suspended on previously strained guys intended for seismic countries]. Moscow. 1994. 18 p. (rus)

3. Chanukvadze G.Sh., Mardzhanishvili M.A.,. Mikabadze Yu.G. Podvesnoe sejsmostojkoe zdanie [Suspended aseismic building]. SU USSR 613065. 1978. (rus)

4. Chanukvadze G.Sh., Mardzhanishvili M.A., Mikabadze Yu.G. Mnogoehtazhnoe sejsmostojkoe zdanie podveshennymi ehtazhami [The multystoried earthquakeresistant building with the suspended floors]. SU USSR 791871.1980. (rus)

5. Ostromensky P.I., Nikiforov I.S., Bolotov A.S Sejsmostojkoe zdanie podvesnogo tipa [Seismic building of suspended type]. Patent RU 2186183. 2002. (rus)

6. Grigorieva I.I. Issledovanie kolebanij podveshennogo perekrytiya pri sejsmicheskom vozdejstvii [The study of oscillations of the suspended ceiling in the seismic impact]. Scientific and Technical VNIIIS abstract collection: a series of 14 Earthquake building. Moscow: VNIIIS State Construction Committee of the USSR. 1979. Vol.8. Pp. 18-21. (rus)

7. De bp-building in Antwerpen [Electronic resource]. URL: http://www.debalansvanbraem.be/braem over bouwen/de _bp_building_in_antwerpen (reference date: 04.06.2016).

8. Hanging a building in air [Electronic resource]. URL http://www.innovation-creativity.com/hanging-a-building-inair.html (reference date: 06.04.2016).

9. Westcoast transmission building [Electronic resource] URL: https://structurae.net/structures/westcoasttransmission-company-tower (reference date: 06.04.2016).

10. Allen E., Zalewski W. Shaping Structures. John Wiley \& Sons. New York, 1998. 416 p.

11. 40 let "4 cilindram» - glavnomu ofisu BMW v Myunhene [40 years "4 cylinders" - BMW head office in Munich] [Electronic resource]. URL: https: //www.press.bmwgroup.com/russia/article/detail/T0143990 RU (reference date: 06.04.2016). (rus)

12. Torres de Colon y un enchufe Art Deco [Electronic resource]. URL: http://www.miradormadrid.com/torrescolon-enchufe-art-deco (reference date: 06.04.2016).

13. The building of the Federal Reserve Bank of Minneapolis (USA). [Electronic resource]. URL: http://synthart.livejournal.com/157725.html (reference date: 06.04.2016).

14. Belash T.A., Rybakov P.L. Zdaniya s podvesnymi konstrukciyami $v$ sejsmicheskih rajonah [Buildings with suspended structures in seismic regions]. Collection of materials of scientific-methodical conference (Problems and achievements in the field of construction engineering). SPb: PGUPS, 2015. Pp. 31-37. (rus)

15. Schuller W. Konstrukcii vysotnyh zdanij [Structures of high-rise buildings]. Translation from English Kilimnik L.Sh., an edition of Kazina G.A. Moscow: Stroyizdat, 1979.

\section{Литература}

1. Корчинский И.Л., Грилль А.А., Чернявский И.3., Попов И.В., Каплан В.Е., Фридбург В.И.. Подвесное здание. А.с. СССР № 477227. 1975.

2. Складнев Н.Н. Высотные здания с жёстким стволом и подвешенными на предварительно напряжённых вантах этажами, предназначенные для сейсмических районов: афтореф. дис. ... канд. техн. наук. М., 1994. $18 \mathrm{c}$.

3. Чануквадзе Г.Ш., Марджанишвили М.А., Микабадзе Ю.Г. Подвесное сейсмостойкое здание. А.с. СССР № 613065. 1978.

4. Чануквадзе Г.Ш., Марджанишвили М.А., Микабадзе Ю.Г. Многоэтажное сейсмостойкое здание с подвешенными этажами. А.с. СССР № 791871. 1980.

5. Остроменский П.И., Никифоров И.С., Болотов А.С. Сейсмостойкое здание подвесного типа. Патент РФ № 2186183. 2002.

6. Григорьева И.И. Исследование колебаний подвешенного перекрытия при сейсмическом воздействии // Научно-технический реферативный сборник. М.: ЦШИС, 1979. Т. 8. 18-21 с.

7. De bp-building in Antwerpen [Электронный ресурc]. URL: http://www.debalansvanbraem.be/braem_over_bouwen/de _bp_building_in_antwerpen\# (дата обращения: 06.04.2016)

8. Hanging a building in air [Электронный ресурc]. URL: http://www.innovation-creativity.com/hanging-a-building-inair.html\# (дата обращения: 06.04.2016).

9. Westcoast transmission building [Электронный ресурс]. URL: http://docomomo.ca/bc2000/type/commercial/westcoast/index.html (дата обращения: 06.04.2016).

10. Allen E., Zalewski W. Shaping Structures. New York: John Wiley \& Sons, 1998. 416 p.

11. 40 лет «4 цилиндрам» - главному офису BMW в Мюнхене [Электронный ресурc]. URL: http://bmwbaltauto.ru/news/1/221/ (дата обращения: 06.04.2016).

12. Torres de Colón [Электронный pecypc]. URL: http://en.wikipedia.org/wiki/Torres_de_Colon (дата обращения: 06.04.2016).

13. Tun Mustapha Tower [Электронный ресурc]. URL: http://en.wikipedia.org/wiki/Tun Mustapha Tower (дата обращения: 06.04.2016).

14. Белаш Т.А., Рыбаков П.Л. Здания с подвесными конструкциями в сейсмических районах // Сборник материалов научно-методической конференции (Проблемы и достижения в области строительного инжиниринга). СПб: ФГБОУ ВПО ПГУПС, 2015. С.3137.

15. Шуллер В. Конструкции высотных зданий / Пер. с анг. Л.Ш. Килимник, ред. Г.А. Казина. М: Стройиздат, 1979. $248 \mathrm{c}$

16. Лобанов В.И. Расчет конструкций с гарантией качества // САПР и графика. 2014. № 11. С. 14-15.

17. Арнольд К., Рейтерман Р. Архитектурное проектирование сейсмостойких зданий / Пер. с анг. Л.Л. Пудовкиной; ред. С.В. Поляков, Ю.С. Волков. М.: Стройиздат, 1987. 195 с.

Belash T.A., Rybakov P.L. Buildings with suspended structures in seismic areas. Magazine of Civil Engineering. 2016. No. 5. Pp. 17-26. doi: 10.5862/MCE.65.2 
248 p. (rus)

16. Lobanov V.I. Raschet konstrukcij s garantiej kachestva [Calculation of structures with guarantee of quality]. CAD and graphics. 2014. No. 11. Pp. 14-15. (rus)

17. Arnold C., Reitherman R. Building Configuration and Seismic Design. John Wiley \& Sons. New York, 1982.

18. Lalin V.V., Rozin L.A., Kushova D.A. Variacionnaya postanovka ploskoj zadachi geometricheski nelinejnogo deformirovaniya i ustojchivosti uprugih sterzhnej [Variation statement of a flat problem of geometrically nonlinear deformation and stability of elastic cores]. Magazine of Civil Engineering. 2013. No. 1(36). Pp. 87-96. (rus)

19. Veryovkin D.G., Mosina N.V., Chubakov M.J. Opyt primeneniya programmnogo kompleksa SCAD Office dlya analiza sistemy sejsmozashchity zdaniya Respublikanskogo nacional'nogo teatra dramy v GornoAltajske [Experience with software SCAD Office complex for the analysis of seismic building system of the Republican National Drama Theater in Gorno-Altaisk]. CADmaster. 2005. No. 4(29). 8 p. (rus)

20. Belyy G.I. Metody rascheta strezhnevyh ehlementov konstrukcij iz tonkostennyh holodnognutyh profilej [Some methods of calculating rod elements of constructions from thin-walled cold-bent profiles]. Vestnik grazhdanskikh inzhenerov. 2014. No. 4(45). Pp. 32-37. (rus)

21. Belyy G.I. K raschetu na ustojchivost' sterzhnevyh ehlementov konstrukcij iz tonkostennyh holodnognutyh profilej [To the calculation of rod element stability of structures made of thin-walled cold-formed profiles]. Vestnik grazhdanskikh inzhenerov. 2016. No. 3(56). Pp. 46-51. (rus)

22. Süleyman Adanur, Murat Günaydin, Ahmet Can Altunişik, Barış Sevim. Construction stage analysis of Humber Suspension Bridge. Applied Mathematical Modelling. 2012 Vol. 36. No. 11. Pp. 5492-5505.

23. Brian J. Sullivan. The finite element method and earthquake engineering: The 2006 Benjamin Franklin Medal in civil engineering presented to Ray W. Clough. Journal of the Franklin Institute. 2010. Vol. 347. No. 4. Pp. 672-680

24. Li Hongnan, Song Benyou, Seismic response reduction for tall buildings by suspended mass pendulums. Earthquake Engineering \& Engineering Vibration. 1995. No. 4(15). Pp. 55-61. (ch)

25. B. Samali, K.C.S. Kwok. Use of viscoelastic dampers in reducing wind- and earthquake-induced motion of building structures. Engineering Structures. 1995. Vol. 17. No. 9. Pp. 639-654.

26. X. Zhaoa, J.M. Ding, H.H. Suna. Structural design of Shanghai Tower for wind loads. Procedia Engineering. 2011. Vol. 14. Pp. 1759-1767.

27. 4 - Friction-vibration interactions. Handbook of FrictionVibration Interactions. 2014. Pp. 153-305.

28. Apaydin N.M., Bas S., Harmandar E. Response of the Fatih Sultan Mehmet Suspension Bridge under spatially varying multi-point earthquake excitations. Soil Dynamics and Earthquake Engineering. 2016. Vol. 84. Pp. 44-54.

29. Apaydın N.M. Earthquake performance assessment and retrofit investigations of two suspension bridges in Istanbul. Soil Dynamics and Earthquake Engineerin. 2010. Vol. 30. No. 8. Pp. 702-710.

30. Mahmoud H., Chulahwat A. Response of building systems with suspended floor slabs under dynamic excitations. Engineering Structures. 2015. Vol. 104. Pp. 155-173.

31. Belash T.A., Uzdin A.M. Issledovaniya $v$ oblasti sejsmostojkogo stroitel'stva $v$ Peterburgskom gosudarstvennom universitete putej soobshcheniya [Researches in the field of aseismic construction at the St.Petersburg State Transport University]. Earthquake Engineering. Safety of Structures. 2015. No. 6. Pp. 15-20.

32. Kalugina-Pablos K.N. Podvesnye konstrukcii ("Gorod v gorode. Parenie") [Suspended designs ("The city in the city. Soaring")]. Science, education and experimental design: Book of Abstracts. Moscow, 2014.Pp. 402-403.

33. Çelebi M., Ulusoy H.S., Nakata N. Responses of a tall

Белаш Т.А., Рыбаков П.Л. Здания с подвесными конструкциями в сейсмических районах // Инженерностроительный журнал. 2016. № 5(65). С. 17-26.
18. Лалин В.В., Розин Л.А., Кушова Д.А. Вариационная постановка плоской задачи геометрически нелинейного деформирования и устойчивости упругих стержней // Инженерно-строительный журнал. 2013. № 1(36). С. 87-96.

19. Веревкин Д.Г., Мосина Н.В., Чубаков М.Ж. Опыт применения программного комплекса SCAD Office для анализа системы сейсмозащиты здания Республиканского национального театра драмы в Горно-Алтайске // CADmaster. 2005. № 4(29). 8 с.

20. Белый Г.И. Методы расчета стрежневых элементов конструкций из тонкостенных холодногнутых профилей // Вестник гражданских инженеров. 2014. № 4(45). С. 32-37.

21. Белый Г.И. К расчету на устойчивость стержневых элементов конструкций из тонкостенных холодногнутых профилей // Вестник гражданских инженеров. 2016. № 3(46). С. 46-51.

22. Süleyman Adanur, Murat Günaydin, Ahmet Can Altunişik, Barış Sevim. Construction stage analysis of Humber Suspension Bridge // Applied Mathematical Modelling. 2012. Vol. 36. № 11. Pp. 5492-5505.

23. Brian J. Sullivan. The finite element method and earthquake engineering: The 2006 Benjamin Franklin Medal in civil engineering presented to Ray W. Clough II Journal of the Franklin Institute. 2010. Vol. 347. № 4. Pp. 672-680.

24. Li Hongan, Song Benyou. Seismic response reduction for Engineering \& Engineering Vibration. 1995. № 4(15). Pp. 55-61.

25. Samali B., Kwok K.C.S. Use of viscoelastic dampers in reducing wind- and earthquake-induced motion of building structures // Engineering Structures. 1995. Vol. 17. № 9. Pp. 639-654.

26. Zhaoa X., Ding J.M., Suna H.H.. Structural design of Shanghai Tower for wind loads // Procedia Engineering 2011. Vol. 14. Pp. 1759-1767.

27. 4 - Friction-vibration interactions // Handbook of frictionvibration interactions. 2014. Pp. 153-305.

28. Apaydin N.M., Bas S., Harmandar E. Response of the Fatih Sultan Mehmet Suspension Bridge under spatially varying multi-point earthquake excitations // Soil Dynamics and Earthquake Engineering. 2016. Vol. 84. Pp. 44-54.

29. Apaydın N.M. Earthquake performance assessment and retrofit investigations of two suspension bridges in Istanbul // Soil Dynamics and Earthquake Engineering. 2010. Vol. 30. № 8. 2010. Pp. 702-710.

30. Mahmoud H., Chulahwat A. Response of building systems with suspended floor slabs under dynamic excitations / Engineering Structures. 2015. Vol. 104. Pp. 155-173.

31. Белаш Т.А., Уздин А.М. Исследования в области сейсмостойкого строительства в Петербургском государственном университете путей сообщения // Сейсмостойкое строительство. Безопасность сооружений. 2015. № 6. С. 15-20.

32. Калугина-Паблос К.Н. Подвесные конструкции («Город в городе. Парение») // Наука, образование и экспериментальное проектирование: сб. тезисов докладов. Москва, 2014. С. 402-403.

33. Celebi M., Ulusoy H.S., Nakata N. Responses of a tal building in Los Angeles, California, as inferred from local and distant earthquakes // Earthquake Spectra. 2016. Vol. 32. № 3. Pp. 1821-1843.

34. Moehle J. Seismic design of reinforced concrete buildings. New York: McGraw-Hill Education, 2014. 760 p.

35. Becker T.C., Yamamoto S., Hamaguchi H., Masahiko Higashino M., Nakashima M. Application of isolation to high-rise buildings: a Japanese design case study through a U.S. design code lens // Earthquake Spectra. 2015. Vol. 31. № 3. Pp. 1451-1470.

36. Giammona A.P., Ryan K.L., Dao N.D.. Evaluation of assumptions used in engineering practice to model tall buildings by suspended mass pendulums // Earthquake 
building in Los Angeles, California, as inferred from local and distant Earthquakes. Earthquake Spectra. 2016. Vol. 32. No. 3. Pp. 1821-1843.

34. Moehle J. Seismic design of reinforced concrete buildings. McGraw-Hill Education. New York, 2014. 760 p.

35. Becker T.C., Yamamoto S., Hamaguchi H., Masahiko Higashino M., Nakashima M. Application of isolation to high-rise buildings: a Japanese design case study through a U.S. Design Code Lens. Earthquake Spectra. 2015. Vol. 31. No. 3. Pp. 1451-1470.

36. Giammona A.P., Ryan K.L., Dao N.D.. Evaluation of assumptions used in engineering practice to model buildings isolated with triple pendulum isolators in SAP2000. Earthquake Spectra. 2015. Vol. 31. No. 2. Pp. 637-660.

37. Uzdin A.M., Elizarov S.V., Belash T. A.. Sejsmostojkie konstrukcii transportnyh zdanij $i$ sooruzhenij: uchebnoe posobie dlya studentov vuzov zheleznodorozhnogo transporta [Earthquake resistant design of transport buildings and structures: the education guidance for students of railway transport]. Moscow: Training center for education on the railways, 2012. $500 \mathrm{p}$ (rus)

38. Arutunyan A.R. Sejsmostojkie konstrukcii transportnyh zdanij i sooruzhenij: uchebnoe posobie dlya studentov vuzov zheleznodorozhnogo transporta [Modern methods of buildings seismic isolation] Magazine of Civil Engineering. 2010. №. 3(13). Pp. 56-60. (rus)

39. Belash T.A., Rybakov P.L. Ob ehffektivnosti ispol'zovaniya konstruktivnyh sistem $\mathrm{s}$ podvesnymi konstrukciyami [The effective use of structural systems of buildings with suspended structures]. Earthquake Engineering. Safety of Structures. 2016. No. 4. Pp. 33-36.

Tatiana Belash,

+7(921)9910115; belashta@mail.ru

Pavel Rybakov,

+7(981)7012491; mojiuctap@gmail.co buildings isolated with triple pendulum isolators in SAP2000. Earthquake Spectra: May 2015, Vol. 31, No. 2. Pp. 637-660.

37. Уздин А.М., Елизаров С.В., Белаш Т.А. Сейсмостойкие конструкции транспортных зданий и сооружений: учебное пособие для студентов вузов железнодорожного транспорта. Москва: Учебнометодический центр по образованию на железнодорожном транспорте, 2012. 500 c.

38. Арутюнян А.Р. Современные методы сейсмоизоляции зданий и сооружений // Инженерно-строительный журнал. 2010. № 3.С. 56-60.

39. Белаш Т.А., Рыбаков П.Л. Об эффрективности использования конструктивных систем с подвесными конструкциями // Сейсмостойкое строительство. Безопасность сооружений. 2016. № 4. С. 33-36.

Татьяна Александровна Белаш, +7(921)9910115; эл. почта: belashta@mail.ru

Павел Леонидович Рыбаков, +7(981)7012491; эл. почта: mojiuctap@gmail.com

(C) Belash T.A., Rybakov P.L., 2016

Belash T.A., Rybakov P.L. Buildings with suspended structures in seismic areas. Magazine of Civil Engineering. 2016. No. 5. Pp. 17-26. doi: 10.5862/MCE.65.2 